\title{
CYTOTOXIC EFFECT OF CRUDE EXTRACT AND FRACTION FROM CALOTROPIS GIGANTEA LEAVES ON HUMAN COLON CANCER WIDR CELL LINES
}

\author{
ROIHATUL MUTIAH ${ }^{1}$, SUKARDIMAN², ATY WIDYAWARUYANTI ${ }^{3}$
}

\author{
${ }^{1}$ Graduate Program, Faculty of Pharmacy, Airlangga University, Surabaya Indonesia, ${ }^{2,3}$ Departement of Pharmacognosy and \\ Phytochemistry, Faculty of Pharmacy, Airlangga University, Surabaya Indonesia \\ Email: roihatulmutiah@gmail.com
}

Received: 22 Sep 2015 Revised and Accepted: 08 Nov 2016

\begin{abstract}
Objectives: This paper sought to understand and determine the cytotoxic's effects of crude extract and its fraction from Calotropis gigantea leaves on human colon cancer WiDr cell lines.
\end{abstract}

Methods: The ethanolic extract was fractionated gradually with certain substances to yield four fractions. The substances were dichloromethane, ethyl acetate, and butanol. The four fractions resulted in dichloromethane fraction, ethyl acetate fraction, butanol fraction, and a water fraction. These fractions were then investigated for their cytotoxic effects on WiDr cells. The cell viability was assessed using MTT colorimetric assay.

Results: The result indicated that the cytotoxic effects of the ethanolic extract $\left(\mathrm{IC}_{50} 48.5 \mu \mathrm{g} / \mathrm{ml}\right.$ ), ethyl acetate fraction (IC ${ }_{50} 41.79 \mu \mathrm{g} / \mathrm{ml}$ ), and dichloromethane fraction ( $\mathrm{IC}_{50} 40.57 \mu \mathrm{g} / \mathrm{ml}$ ) produced a much more potent effect than the butanol fraction (IC $50737.74 \mu \mathrm{g} / \mathrm{ml}$ ) and water fraction (IC $508493 \mu \mathrm{g} / \mathrm{ml})$.

Conclusion: The ethanolic extract, ethyl acetate fraction and dichloromethane fraction exhibited a potent cytotoxic effect on human colon cancer WiDr cell line. The crude extract and fractions are potential to be developed as an anticancer agent in colon cancer therapy.

Keywords: Cytotoxic, Calotropis gigantea, WiDr cells, Colon cancer.

(C) 2017 The Authors. Published by Innovare Academic Sciences Pvt Ltd. This is an open access article under the CC BY license (http://creativecommons.org/licenses/by/4. 0/) DOI: http://dx.doi.org/10.22159/ijpps.2017v9i1.9022

\section{INTRODUCTION}

Cancer disease has developed into a serious problem of health because of its increasing occurrences year by year. World Health Organization (WHO) stated that there are more than 10 million cancer cases every year in the world. In the United States, colorectal cancer is reported to be the third most common cancer in both men and women. There were 106,480 cases of colon and 40,340 cases of rectal cancer had been founding 2012. In 2009, there were 50,830 deaths from colorectal cancer. These mortality cases were totaled in almost nine percent of all cancer deaths [1]. Despite advances in the management of this condition, such as improved surgical techniques, the use of chemo or radiotherapy has not significantly decreased cancer mortality rate in decades. These treatment methods have mostly been useful for early detection of cancer. However, they are not as effective in treating cancer cases in the metastasis stage. Cancer treatment failure, particularly through chemotherapy, can happen because of low selectivity of the cytotoxic and uncertainty degree of the molecular targeted. Several studies have been conducted to shed light on the effects and functions of the cytotoxic agent from the medicinal plant as a means to prevent and treat colon cancer.

Calotropis gigantea (Apocynaceae) is a medicinal plant that are widely grown in Asia, especially in Indonesia, Bangladesh, China, Burma, Malaysia, Pakistan, Philippines, Thailand and Srilanka. The plant has been traditionally used for treating inflammation, abscess, scabies, cough, trachoma, constipation, asthma, toothache, gastritis, otitis media, and dysentery [2]. Previous studies investigated several pharmacological properties of this plant. For instance, the leaves of this plant were reported to be effective for anti-diarrhea treatment [3], antibacterial remedy [4], anticandida [5], and antioxidant agency [6]. The flowers were shown to be useful for antibacterial antidote [7], the cytotoxic agency [8], and analgesic procedure [9]. Roots were claimed to be potent for antipyretic conditioning [10], cytotoxic agency [8], antimicrobial treatment [11], insecticidal activity [12], wound healing activity [13], CNS activity [14], and pregnancy interceptive properties [15]. The latex of the plant exhibited to contain purgative properties and procoagulant agencies [16], effective within wound healing processes [17], and antimicrobial remedy [18]. The stem was also reported to possess hepatoprotective effects [19].

In Previous study Calotropis gigantea roots extract (IC50-3.3, 7.0 $\mathrm{mg} / \mathrm{ml}$ ), Coroglaucigenin ( $\mathrm{IC}_{50}-4.7,14.1 \mathrm{mg} / \mathrm{ml}$ ) and Frugoside $\left(\mathrm{IC}_{50}-\right.$ $3.4,6.5 \mathrm{mg} / \mathrm{ml}$ ) showed signi ficant activity against K562 and SGC-7901 cell lines [20]. Active compounds from roots that have been isolated are 19-dihydrocalactin ( $\mathrm{IC}_{50}-0.026 \mu \mathrm{M}, 0.047 \mu \mathrm{M}$ ), calactin $\left(\mathrm{IC}_{50}-0,022 \mu \mathrm{M}\right.$, $0.028 \mu \mathrm{M}$ ), calotropin ( $\mathrm{IC}_{50}-0.029 \mu \mathrm{M}, 0.046 \mu \mathrm{M}$ ) showed cytotoxic activity against human A549 and Hela cell lines [21]. In this study, we investigated the cytotoxic effects of fractions within the ethanolic extract of Calotropis gigantea leaves on colon cancer WiDr cell line.

\section{MATERIALS AND METHODS}

\section{Materials}

Calotropis gigantea leaves were collected and identified in Lembaga Ilmu Pengetahuan Indonesia (LIPI) Purwodadi, East Java, Indonesia. Materials collected for cytotoxic assay were identified as [3-(4, 5dimetilthiazol-2-yl)-2, 5-diphenyl tetrazolium bromide] (MTT) (Sigma Chemical, St Loius, MO), $\mathrm{H}_{2} \mathrm{O}_{2}$ (Lab Vision Plus), chromogen 3, 3-diaminobenzidin (DAB) (Novo Castra).

Preparation of ethanolic extract and fractions of Calotropis gigantea

Dried powder of Calotropis gigantea was extracted using ethanol $70 \%$ with a ratio of $1: 10$ for $72 \mathrm{~h}$. Then, the filtrate obtained was filtered while the sediment was re-extracted using ethanol $70 \%$ at a ratio of 1:8 for $72 \mathrm{~h}$. The re-extraction was performed twice. The extract was then collected and evaporated under reduced pressure to give of viscous ethanolic extract. The extract was added with 100 $\mathrm{ml}$ aqua dest and then mixed to yield a liquid form of ethanolic extract. The extract was fractionated with dichloromethane at a ratio of 1:1 resulting in the dichloromethane fraction and residue. The residue then fractionated using ethyl acetate at a ratio of 1:1 and yielded in ethyl acetate fraction and residue. The residue was then fractionated using butanol at ratio 1:1 with the result of butanol fraction and residue. The residue was categorised as water fraction. 


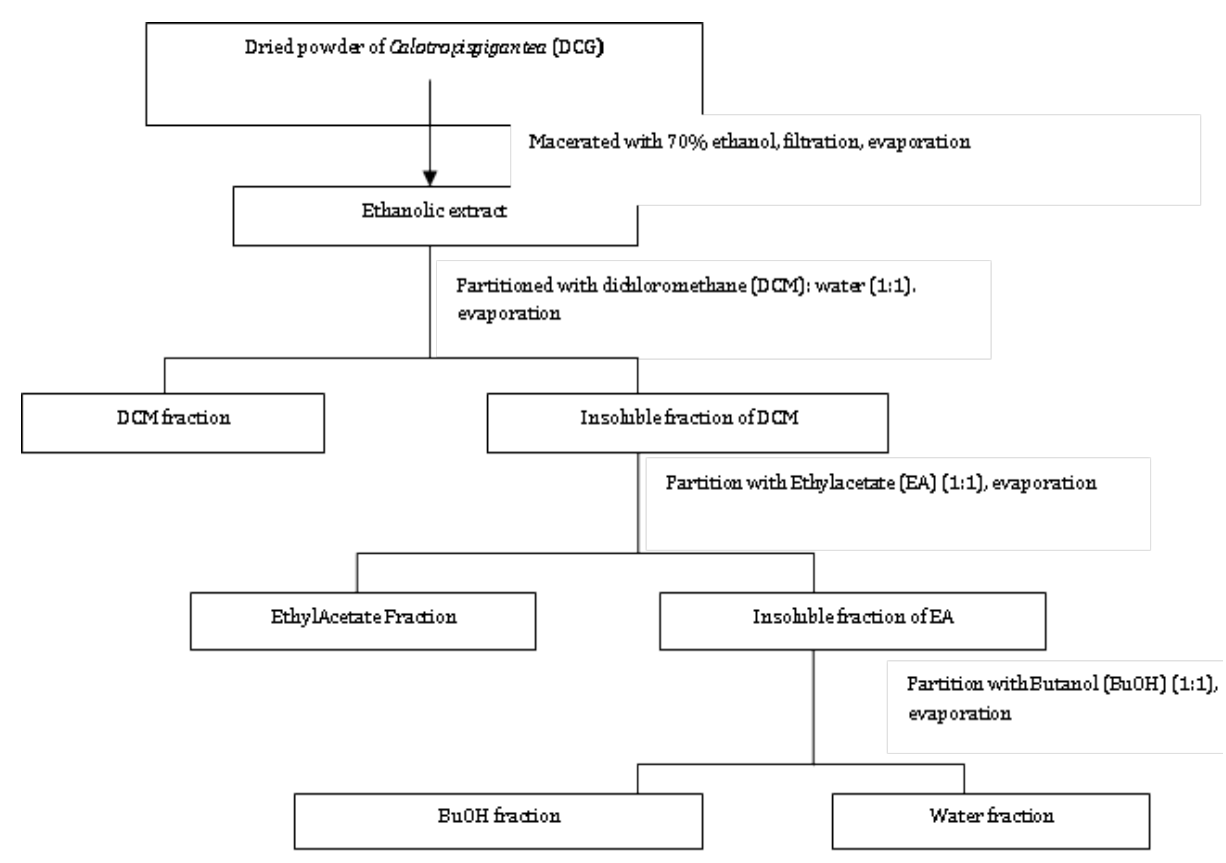

Fig. 1: Procedure for obtaining fractions of Calotropis gigantea leaves using ethanolic extract

\section{Human colon cancer cell lines}

Human colon cancer WiDr was kindly provided by Prof. Masashi Kawaichi, Nara Institute Science and Technology (NAIST). The cells were routinely grown in DMEM containing $10 \%$ FBS, $1 \%$ Penicillinstreptomycin (v/v), and L-glutamine $(1 \mathrm{mmol})$ at $37^{\circ} \mathrm{C}$ and $5 \% \mathrm{CO}_{2}$.

\section{Cytotoxic assay}

The human colon cancer WiDr cell lines were cultured in 96-well plates (Becton Dickinson Co., NJ, USA), and each well contained the $5 \times 10^{3}$ cells. The culture cells were incubated in a humidified incubator at $37{ }^{\circ} \mathrm{C}$ in an atmosphere of $5 \% \mathrm{CO}_{2}$ and $95 \%$ air for $24 \mathrm{~h}$. The cell confluence or the crowding of cells in the plate was about $70-80 \%$. After a 24-hour incubation, the culture medium was discarded. The cells were treated by Calotropis gigantea extract and fractions (within treatment groups) or the vehicle (control group), and then incubated for $24 \mathrm{~h}$. The concentrations of the fraction were $1,10,100,500$ and $1000 \mu \mathrm{g} / \mathrm{ml}$ in DMEM. After incubation, the cells were incubated with $0.5 \mathrm{mg} / \mathrm{ml}$ MTT for $4 \mathrm{~h}$ in $37^{\circ} \mathrm{C}$. Viable cells reacted with MTT to produce purple formazan crystals. After $4 \mathrm{~h}$, the stopper of $10 \%$ SDS (Sigma Co., St. louis, MO) in $0.01 \mathrm{~N} \mathrm{HCl}$ (Merck) was added to dissolve the formazan crystal. The cells were then incubated for $24 \mathrm{~h}$ in room temperature and protected from light. After incubation, the cells were shaken, and cells absorbance was measured using ELISA reader at $\lambda 595 \mathrm{~nm}$.

\section{Data analysis}

The experimental data was the absorbance of each well, which was then converted to a percentage of the viable cells as described below.
Percentage of viable cells $=[\mathrm{B}-\mathrm{C} / \mathrm{A}-\mathrm{C}] \times 100 \%$.

$\mathrm{A}, \mathrm{B}$ and $\mathrm{C}$ were absorbance of control group, treatment group and medium, respectively. The potency of cytotoxic effect was represented by $\mathrm{IC}_{50}$ value and calculated using probit analysis. $\mathrm{IC}_{50}$ value represents a concentration of the fractions that produce cells death of $50 \%$. Calculation of IC $_{50}$ values was based on a linear regression correlation between logarithms of concentration versus probit value of the percentage of cell viability.

\section{Thin layer chromatography (TLC)}

Detection and separation of active compound of crude extract and its fractions with TLC were carried out using silica gel $\mathrm{F}_{254}$ in stationary phase and chloroform: methanol $(95: 5 \mathrm{v} / \mathrm{v})$ in the mobile phase.

\section{Statistical analysis}

All data were classified as mean \pm SD. One method of variance analysis (ANOVA) followed by the least significant difference (LSD) test was used for statistical analysis.

\section{RESULTS AND DISCUSSION}

In this study, Calotropis gigantea leaves were extracted using ethanol 70 $\%$ that can extract polar, semi-polar, and nonpolar compounds. Subsequently, the ethanolic extract was fractionated gradually with dichloromethane, ethyl acetate, and butanol and resulted in four fractions. These fractions were dichloromethane fraction, ethyl acetate fraction, butanol fraction, and a water fraction. The procedure to gain these fractions was described in fig. 1. This research sought to determine the impact of these fractions on WiDr cell line. The potency of cytotoxic effects of each fraction was then compared using $\mathrm{IC}_{50}$ values.
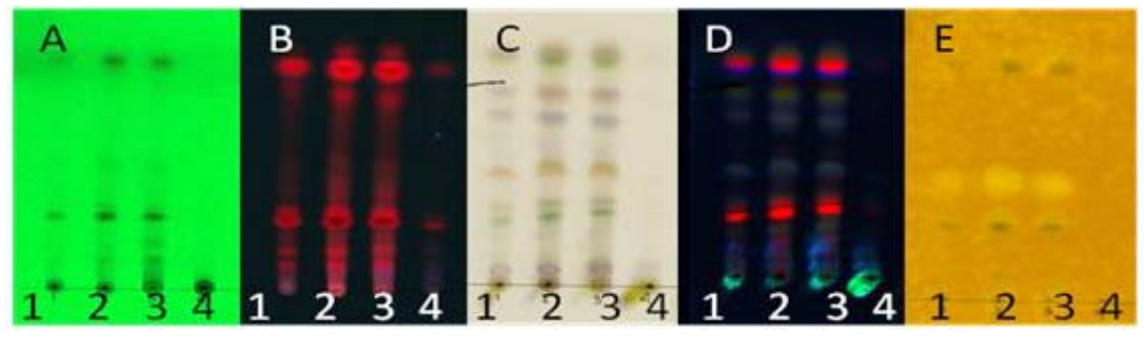

Fig. 2: TLC profile of ethanolic extract (1), dichloromethane fraction (2), ethyl acetate fraction (3), butanol fraction (4). Stationary phase: silika gel $F_{254}$. Mobile phase: methanol: chloroform $(95: 5 v / v)$. a: $\mathrm{UV}_{254}$, b: $\mathrm{UV}_{366}$, c: after spray with $\mathrm{H}_{2} \mathrm{SO}_{4} \mathrm{10}_{0}, \mathrm{~d}: \mathrm{UV}_{366}$ after spray with $\mathrm{H}_{2} \mathrm{SO}_{4} 10 \% ; 105{ }^{\circ} \mathrm{C}$, e: with Dragendorf reagent 
Effect of ethanolic extract and fractions on WiDr colon cancer cell line

The potency test of ethanolic extract and fractions of Calotropis gigantea leaves was performed on WiDr cells as a model of human colon cancer. The concentrations of the extract used were 1, 10, 100, 500 and 1000 $\mu \mathrm{g} / \mathrm{ml}$. Cell viability was examined using MTT reagent after a $24 \mathrm{~h}$ incubation. Fig. 3 displays the effect of a series of concentration: ethanolic extract, dichloromethane fraction, and ethyl acetate fraction. These fractions were able to decrease the cell viability significantly $(p<0.05)$ in a concentration-dependent manner. Butanol fraction and water fraction did not decrease the cell viability $(p>0.05)$. IC50 value of ethanolic extract, dichloromethane fraction, ethyl acetate fraction, butanol fraction, and water fraction were $48.5 \mu \mathrm{g} / \mathrm{ml}, 40.57 \mu \mathrm{g} / \mathrm{ml}, 41.79$ $\mu \mathrm{g} / \mathrm{ml}, 737.74 \mu \mathrm{g} / \mathrm{ml}$ and $8493 \mu \mathrm{g} / \mathrm{ml}$ respectively (table 1 ). The findings indicate that dichloromethane and ethyl acetate fraction were more potent than the other fractions.

The TLC profile on fig. 2 shows that ethanolic extract, dichloromethane and etyl acetate fraction contained flavonoid and terpenoid compounds. Such compounds have been known to have an anticancer potency. Isorhamnetin-3-O-rutinoside, Isorhamnetin-3-O-Glucopyranoside, Taraxasteryl acetate are a flavonoid compound of $C$. gigantea leaves [22] The leaves of $C$. gigantea contain a cardenolide glycoside compound. The compound consists of 12 $\alpha$-hydroxy coroglaucigenin, calotoxin/ calotropin, calotropagenin. Its coumpound demonstrated a cytotoxic potency against KB, MCF7 dan, NCI-H187cell lines [23]. Calotropin from Calotropis procera have been known to have cytotoxic potency against Leukemia K562 Cell lines by the mechanism of cell cycle regulations with inhibited G2 phase and caspase-3 activation [24].

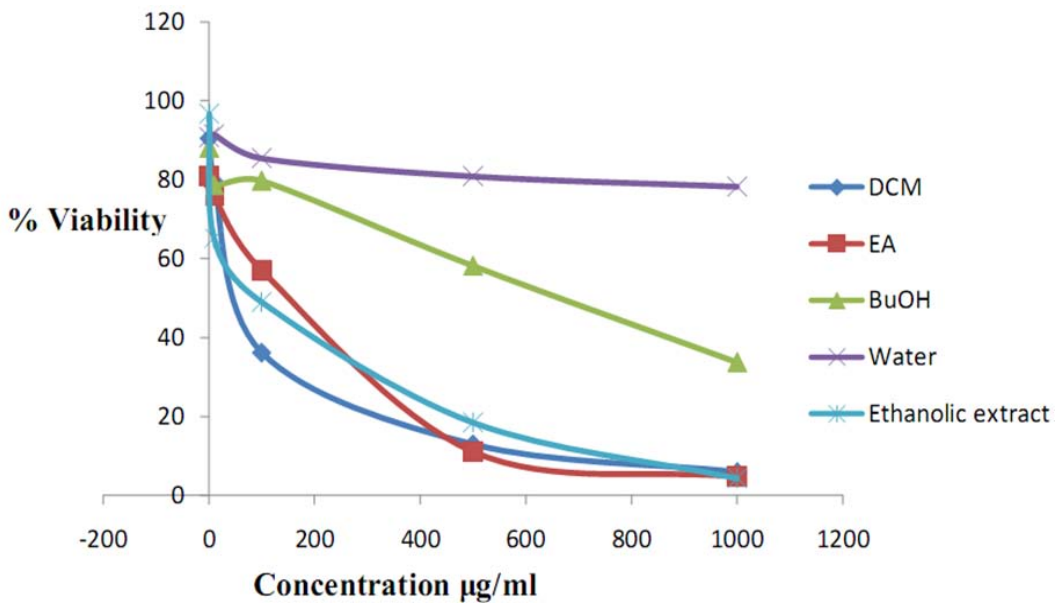

Fig. 3: Effect of ethanolic extract, dichloromethane fraction (DCM), ethyl acetate fraction (EA), butanol fraction (BuOH) and water fraction of Calotropis gigantea on WiDr cell viability. Cells were incubated for $24 \mathrm{~h}$ with various concentrations of ethanolic extract. Cell proliferation was examined using MTT assay

Table 1: The IC 50 value of cytotoxic of ethanolic extract and fractions of Calotropis gigantea leaves on human colon cancer WiDr cell

\begin{tabular}{ll}
\hline Samples & IC $_{\mathbf{5}}{ }^{*}(\boldsymbol{\mu g} / \mathbf{m l}) \pm$ SD \\
\hline Ethanol extract & $48.50 \pm 2.39$ \\
Dichloromethane fraction & $40.57 \pm 8.74$ \\
Ethyl acetate Fraction & $41.79 \pm 8.48$ \\
Butanol Fraction & $737.74 \pm 25.38$ \\
Water Fraction & $8493 \pm 30.48$ \\
Doxorubicin & $9.27 \pm 0.57$ \\
\hline
\end{tabular}

*Values are mean \pm SD of triplicates
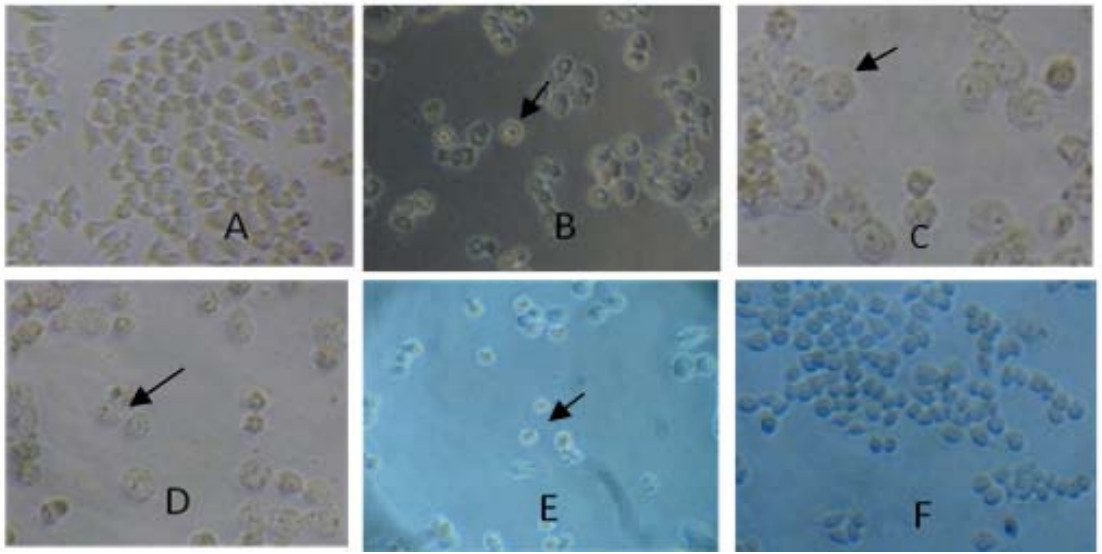

Fig. 4: The cell morphology of ethanolic extract at a dose of $10 \mu \mathrm{g} / \mathrm{ml}$ (A), Doxorubicin at a dose $50 \mu \mathrm{g} / \mathrm{ml}$ (B), dichloromethane fraction at dose of $10 \mu \mathrm{g} / \mathrm{ml}(C)$, ethyl acetate fraction at a dose of $10 \mu \mathrm{g} / \mathrm{ml}$ and (D), butanol fraction at a dose of $10 \mu \mathrm{g} / \mathrm{ml}$ (E), and water fraction at a dose of $10 \mu \mathrm{g} / \mathrm{ml}$ (F). The cellular morphology of cell was examined under a microscope (x400). The result was obtained from one representative data of nine experiments that demonstrated a similar result. Each point represented the mean \pm SD of nine experiments 


\section{CONCLUSION}

We concluded that ethanolic extract, dichloromethane fraction, and ethyl acetate fraction exhibited a potent cytotoxic on human colon cancer WiDr cell line. Thus, these extracts were potential to be developed as an anticancer agent in human colon cancer therapy.

\section{ACKNOWLEDGEMENT}

We deeply thank the DP2M DIKTI (Directorate of Higher Education) Ministry of Education, Indonesia, for their financial support through "HIBAH KERJASAMA PERGURUAN TINGGI (PEKERTI)" Research Grant in 2014 that made this study possible.

\section{CONFLICTS OF INTERESTS}

Declared none

\section{REFERENCES}

1. National Cancer Institude (NCI). Database Colon and Rectal Cancer. The National Institutes of Health; 2013.

2. Mardisiswojo, Radjakmanugunsudarso. $2^{\text {nd }}$ ed. Cabe Puyang Warisan Nenek Moyang; 1968.

3. Chitme HR, Chandra R, Kaushik S. Studies on the antidiarrheal activity of Calotropis gigantea in experimental animals. J Pharm Pharm Sci 2004;7:70-5.

4. Kumar G, Karthik L, Bhaskara Rao KV. Antibacterial activity of aqueous extract of Calotropis gigantean Leaves an in vitro study. Int J Pharm Sci Rev Res 2010;4:141-4.

5. Kumar G, Karthik L, Bhaskara Rao KV. In the vitro anticandida activity of Calotropis gigantean against clinical isolates of candida. J Pharm Res 2010;3:539-42.

6. Singh N, Jain NK, Kannojia P, Garud N, Pathak AK, Mehta SC. In vitro antioxidant activity of Calotropis gigantean hydroalcoholic leaves extract. Der Pharm Lett 2010;2:95-100.

7. Habib MR, Karim MR. The antimicrobial and cytotoxic activity of Di-(2-ethylhexyl) phthalate and anhydrosophoradiol-3-acetate Isolated from Calotropis gigantea (Linn.) flower. Mycobiology 2009;37:31-6.

8. Wang Z, Wang M, Mei W, Han Z, Dai H. A new cytotoxic pregnanone from Calotropis gigantea. Molecules 2008;13:3033-9.

9. Pathak AK, Argal A. Analgesic activity of Calotropis gigantean flower. Fitoterapia 2007;78:40-2.

10. Chitme HR, Chandra R, Kaushik S, Evaluation of the antipyretic activity of Calotropis gigantea (Asclepiadaceae) in experimental animals. Photother Res 2005;19:454-6.

11. Alam MA, Habib MR, Nikkon R, Rahman M, Karim MR. Antimicrobial activity of akanda (Calotropis gigantea L.) on some pathogenic bacteria. Bangladesh J Sci Ind Res 2008;43:397-404.

12. Alam MA, Habib MR, Nikkon F, Khalequzzaman M, Karim MR. Insecticidal activity of root bark of Calotropis gigantea $\mathrm{L}$. against Tribolium castaneum (Herbst). World J Zool 2009;4:905.

13. Deshmukh PT, Fernandes J, Aarte A, Toppo E. Wound healing activity of Calotropis gigantean root bark in rats. J Ethnopharmacol 2009;125:178-81.

14. Argal A, Pathak AK. CNS activity of Calotropis gigantea roots. J Ethnopharmacol 2006;106:142-5.

15. Srivastava SR, Keshri G, Bhargavan B, Singh C, Singh MM. Pregnancy interceptive activity of the roots of Calotropis gigantea Linn. In rats. Contraception 2007;75:318-22.

16. Rajesh R, Raghavendra GCD, Nataraju A, Dhananjaya BL, Kemparaju K, Vishwanath BS. Procoagulant activity of Calotropis gigantean latex-associated with the fibrinogenolytic activity. Toxicon 2005;46:84-92.

17. Nalwaya N, Pokharna G, Deb L, Jain NK. Wound healing activity of latex of Calotropis gigantea. Int J Pharm Pharm Sci 2009;1:176-81.

18. Kumar G, Karthik L, Bhaskara Rao KV. Antimicrobial activity of latex of Calotropis gigantea against pathogenic microorganisms an in vitro study. Pharmacology online 2010;3:155-63.

19. Lodhi G, Singh HK, Pant KK, Hussain Z. Hepatoprotective effects of Calotropis gigantea extract against carbon tetrachlorideinduced liver injury in rats. Acta Pharm 2009;59:89-96.

20. Wang ZN, Wang NY, Mei LW, Han Z, Dai HF. A new cytotoxic pregnanone from Calotropis gigantea. Molecules. 2008;13:3033-9.

21. You H, Min L, Song W, Chen H, Meng Y, Guo D, et al. Cytotoxic cardenolides from the root bark of Calotropis gigantea. Steroids 2013;78:1029-34.

22. Sen S, Sahu NP, Mahato SB. Flavonol glycosides from Calotropis gigantean. Phytochemistry 1992;31:2919-21.

23. Seeka C, Sutthivaiyakit S. Cytotoxic cardenolid from the leaves of Calotropis gigantea. Chem Pharm Bull 2010;58:725-8.

24. Wang CS, Lu CM, Chen LH, Tseng IH, Ke YY, Wu CY, et al. Cytotoxicity of calotropin is through caspase activation and downregulation of anti-apoptotic proteins in K562 cells. Cell Biol Int Elsevier 2009;13:1230-6.

\section{How to cite this article}

- Roihatul Mutiah, Sukardiman, Aty Widyawaruyanti. Cytotoxic effect of crude extract and fraction from Calotropis gigantea leaves on human colon cancer widr cell lines. Int J Pharm Pharm Sci 2017;9(1):83-86. 